Wahana Didaktika Vol. 18 No.1 Januari 2020 : 30-38

\title{
PENINGKATAN HASIL BELAJAR IPA MELALUI METODE PEMBELAJARAN DEMONSTRASI
}

\author{
Oleh: Ermawati \\ (Guru SMP Negeri 36 Palembang) \\ Email: ermawati@gmail.com
}

\begin{abstract}
Abstrak
Tujuan dari penelitian tindakan ini adalah untuk meningkatkan hasil belajar IPA melalui metode demonstrasi pada peserta didik kelas VII.D di SMP Negeri 36 Palembang. Penelitian ini menggunakan penelitian tindakan kelas sebanyak dua siklus. Setiap siklus terdiri dari empat tahap yaitu : perencanaan, pelaksanaan, pengamatan, refleksi. Sasaran penelitian ini adalah peserta didik kelas VII.D SMP Negeri 36 Palembang. Data yang diperoleh adalah data kuantitatif dan kualitatif. Dari hasil analisis metode pembelajaran Demonstrasi memiliki dampak positif dalam meningkatkan hasil belajar peserta didik yang ditandai dengan peningkatan ketuntasan belajar peserta didik dalam setiap siklus, yaitu pra siklus (43,75\%), Siklus 1 (62,50\%), dan siklus 2 (87,50\%). Kesimpulan dari penelitian ini adalah metode pembelajaran Demonstrasi dapat meningkatkan hasil belajar peserta didik yang ditunjukan dengan rata-rata jawaban peserta didik yang menyatakan bahwa peserta didik tertarik dan berminat dengan metode pembelajaran Demonstrasi sehingga mereka menjadi termotivasi untuk belajar.
\end{abstract}

Kata Kunci: Hasil Belajar, IPA, Demonstrasi

\section{IMPROVEMENT OF SCIENCE LEARNING OUTCOMES DEMONSTRATION LEARNING METHOD}

\begin{abstract}
The purpose of this action research is to improve the learning outcomes of science through a demonstration method in class VII.D students in Palembang Public Middle School 36. This study used classroom action research in two cycles. Each cycle consists of four stages, namely: planning, implementation, observation, reflection. The target of this study was students of class VII.D SMP Negeri 36 Palembang. The data obtained are quantitative and qualitative data. From the results of the analysis of the Demonstration learning method has a positive impact in improving student learning outcomes which is characterized by an increase in mastery learning in each cycle, namely pre cycle (43.75\%), Cycle 1 (62.50\%), and cycle 2 ( 87.50\%) The conclusion of this study is that the demonstration learning method can improve student learning outcomes as indicated by the average answers of the students stating that students are
\end{abstract}


Peningkatan Hasil Belajar....(Ermawati)

interested and interested in Demonstration learning methods so that they become motivated to learn

Keywords: Learning Outcomes, Science, Demonstrations

\section{A. PENDAHULUAN}

Menurut Permendiknas Nomor 22 Tahun 2006 tentang Standar Isi, IPA merupakan ilmu universal yang mendasari perkembangan teknologi modern, mempunyai peran penting dalam berbagai displin dan memajukan daya pikir manusia. Perkembangan pesat di bidang teknologi informasi dan komunikasi dewasa ini dilandasi oleh perkembangan IPA dibiadang teori bilangan, aljabar, analisis, teori peluang dan IPA diskrit. Untuk menguasai dan mencipta teknologi di masa depan diperlukan penguasaan IPA yang kuat sejak dini.

Mata pelajaran IPA perlu diberikan kepada semua peserta didik mulai dari sekolah dasar untuk membekali peserta didik dengan kemampuan berpikir logis, analitis, sistematis, kritis, dan kreatif, serta kemampuan bekerjasama. Kompetensi tersebut diperlukan agar peserta didik dapat memiliki kemampuan memperoleh, mengelola, dan memanfaatkan informasi untuk bertahan hidup pada keadaan yang selalu berubah, tidak pasti, dan kompetitif

Namun berdasarkan data, bagi sebagain peserta didik banyak yang beranggapan bahwa mata pelajaran IPA adalah pelajaran yang menakutkan dan sulit. Hal ini tebukti dari data ulangan harian peserta didik tanggal 3 Februari 2018, masih terdapat banyak peserta didik yang di bawah KKM yaitu sebesar $53.33 \%$ (16 peserta didik) yang mendapat nilai di atas KKM (75) dari 32 peserta didik di SMP Negeri 36 Palembang.

Rendahnya hasil belajar peserta didik pada mata pelajaran IPA, diduga disebabkan oleh ketidaksesuaian penggunaan metode pembelajaran yang digunakan guru dalam mengajarkan suatu materi dalam pembelajaran IPA. Selain itu, guru masih menggunakan metode pembelajaran lama yang hanya menyajikan materi tanpa memberi kesempatan kepada peserta didik salah satunya adalah metode konvensional atau metode ceramah. Oleh karena itu, guru dituntut untuk 
memahami dan menerapkan beragam metode pembelajaran agar peserta didik aktif dalam belajar. Salah satu metode yang tepat dalam pembelajaran IPA yaitu metode demonstrasi. Metode demonstrasi adalah metode penyajian pelajaran dengan memperagakan dan mempertunjukan kepada peserta didik tentang suatu proses, situasi benda tertentu, baik sebenarnya maupun hanya tiruan.

Berdasarkan uraian di atas maka penulis merumuskan masalah sebagai berikut: “Apakah melalui metode demonstrasi dapat meningkatkan hasil belajar IPA pada kelas VII.D di SMP Negeri 36 Palembang?”. Berdasarkan rumusan masalah di atas, maka tujuan dalam penelitian ini adalah untuk mengetahui peningkatan hasil belajar IPA melalui metode Demonstrasi pada peserta didik kelas VII.D di SMP Negeri 36 Palembang.

Menurut Slameto (2010:2) Belajar ialah suatu proses usaha yang dilakukan seseorang untuk memperoleh suatu perubahan tingkah laku yang baru secara keseluruhan, sebagai hasil pengalamannya sendiri dalam interaksi dengan lingkungannya. Menurut Syah (2005:68), belajar adalah seluruh tingkah laku individu yang relatif menetap sebagai hasil pengalaman dan interaksi dengan lingkungan yang melibatkan proses koqnitif. Dari beberapa pendapat di atas, dapat ditarik kesimpulan bahwa belajar adalah suatu proses usaha yang dilakukan seseorang untuk memperoleh suatu perubahan tingkah laku yang baru sebagai hasil pengalaman dan inteaksi dengan lingkungan yang melibatkan proses koqnitif.

Menurut Permendiknas Nomor 22 Tahun 2006 tentang Standar Isi, IPA merupakan ilmu universal yang mendasari perkembangan teknologi modern, mempunyai peran penting dalam berbagai displin dan memajukan daya pikir manusia. Perkembangan pesat di bidang teknologi informasi dan komunikasi dewasa ini dilandasi oleh perkembangan IPA dibiadang teori bilangan, aljabar, analisis, teori peluang dan IPA diskrit. Untuk mengusasi dan mencipta teknologi di masa depan diperlukan penguasaan IPA yang kuat sejak dini. Mata pelajaran IPA perlu diberikan kepada semua peserta didik mulai dari sekolah dasar untuk membekali peserta didik dengan kemampuan berpikir logis, analitis, sistematis, 
kritis, dan kreatif, serta kemampuan bekerjasama. Kompetensi tersebut diperlukan agar peserta didik dapat memiliki kemampuan memperoleh, mengelola, dan memanfaatkan informasi untuk bertahan hidup pada keadaan yang selalu berubah, tidak pasti, dan kompetitif.

Metode demonstrasi adalah pertunjukan tentang proses terjadinya suatu peristiwa atau benda sampai pada penampilan tingkah laku yang dicontohkan agar dapat diketahui dan dipahami oleh peserta didik secara nyata atau tiruannya (Djamarah, 2008:210). Metode demonstrasi adalah metode mengajar dengan cara memperagakan barang, kejadian, aturan, dan urutan melakukan suatu kegiatan, baik secara langsung maupun melalui penggunaan media pengajaran yang relevan dengan pokok bahasan atau materi yang sedang disajikan (Syah, 2000:22).

Sementara Djamarah, (2000:2) bahwa metode demonstrasi adalah metode yang digunakan untuk memperlihatkan sesuatu proses atau cara kerja suatu benda yang berkenaan dengan bahan pelajaran. Menurut Djamarah (2008:210) metode demonstrasi ini lebih sesuai untuk mengajarkan bahan-bahan pelajaran yang merupakan suatu gerakan-gerakan, suatu proses maupun hal-hal yang bersifat rutin.

Dengan metode demonstrasi peserta didik berkesempatan mengembangkan kemampuan mengamati segala benda yang sedang terlibat dalam proses serta dapat mengambil kesimpulan-kesimpulan yang diharapkan. Menurut Sanjaya (2006:15) metode Demonstrasi adalah penyajian pembelajaran dengan memperagakan dan mempertunjukkan pada peserta didik tentang suatu proses, situasi atau benda tertentu, baik sebenarnya atau hanya sekedar.

\section{B. METODOLOGI PENELITIAN}

Penelitian ini termasuk dalam jenis penelitian tindakan kelas (PTK). Ciri utama dari penelitian tindakan kelas yakni adanya tindakan-tindakan tertentu untuk memperbaiki dan menyempurnakan proses pembelajaran di kelas. Penelitian tindakan kelas yang digunakan adalah penelitian partisipan dimana peneliti terlibat secara langsung dan penuh dalam penelitian mulai dari awal 
sampai akhir penelitian. Penelitian ini dilaksanakan di SMP Negeri 36 Palembang, dipilihnya sekolah ini sebagai tempat meneliti karena peneliti adalah sebagai guru mata pelajaran IPA di SMP tersebut.

Adapun waktu penelitian ini dilaksanakan pada bulan Februari sampai dengan bulan Maret 2018. Subjek yang dimaksud tindakan dalam penelitian ini adalah peserta didik kelas VII.D SMP Negeri 36 Palembang yang berjumlah 32 peserta didik. Mereka merupakan peserta didik-siswi kelas VII.D semester 2 2018, sedangkan partisipan yang terlibat dalam penelitian ini adalah guru kelas dan teman sejawat lainnya.

Penelitian ini menggunakan metode penelitian tindakan kelas (PTK). Hal ini disesuaikan dengan karakeristik penelitian tindakan kelas, yaitu masalah yang harus dipecahkan berasal dari persoalan praktik pembelajaran di kelas atau berangkat dari permasalahan praktik faktual. Model penelitian tindakan kelas ini merujuk pada model Kemmis dan MC Taggart yang menguraikan bahwa tindakan yang digambarkan sebagai suatu proses yang dinamis dari aspek perencanaan, tindakan (pelaksanaan), observasi (pengamatan), refleksi.

\section{HASIL PENELITIAN DAN PEMBAHASAN}

Dari tabel di bawah dapat dijelaskan bahwa sebelum menerapkan metode pembelajaran Tanya jawab diperoleh rata - rata hasil belajar peserta didik yaitu 64,22 dengan presentase $43,75 \%$ atau 14 peserta didik dari 32 peserta didik yang tuntas belajar. Hasil tersebut menunjukkan bahwa pada pra siklus secara klasikal peserta didik belum tuntas belajar, karena hanya 14 peserta didik yang memperoleh nilai $\geq 75$ atau hanya sebesar $43,75 \%$ yang mencapai kriteria ketuntasan minimum (KKM). Sehingga, masih terdapat 18 dari 32 peserta didik yang belum tuntas belajar atau sebanyak 56,25\%. hasil tersebut lebih kecil dari presentase ketuntasan klasikal dalam proses pembelajaran IPA yang dikehendaki sebesar $85 \%$. 
Tabel 1. Rekapitulasi Hasil Tes Formatif Pada Pra siklus

\begin{tabular}{|c|l|c|}
\hline No. & \multicolumn{1}{|c|}{ Uraian } & Hasil Siklus I \\
\hline \hline 1. & Nilai rata-rata tes formatif & 64,22 \\
\hline 2. & Jumlah siswa yang tuntas belajar & 14 \\
\hline 3. & Persentase ketuntasan belajar & 43,75 \\
\hline
\end{tabular}

Berdasarkan kenyataan- kenyataan di atas, peneliti dibantu oleh teman sejawat melakukan kajian dan telah yang akan dipergunakan sebagai dasar pertimbangan memilih strategi pembelajaran yang tepat, dalam upaya melakukan tindakan perbaikan pembelajaran IPA. Setelah berdiskusi dan mempertimbangkan berbagai alasan tersebut, peneliti memilih metode pembelajaran demonstrasi. Metode ini dipergunakan dalam PTK yang akan dilaksanakan pada saat berlangsungnya proses pembelajaran di kelas VII.D SMP Negeri 36 Palembang, yang diharapkan dapat meningkatkan hasil belajar IPA pada peserta didik kelas tersebut.

Tabel 2 Rekapitulasi Hasil Tes Formatif Pada Siklus I

\begin{tabular}{|c|l|c|}
\hline No. & \multicolumn{1}{|c|}{ Uraian } & Hasil Siklus I \\
\hline \hline 1. & Nilai rata-rata tes formatif & 72,19 \\
\hline 2. & Jumlah siswa yang tuntas belajar & 20 \\
\hline 3. & Persentase ketuntasan belajar & 62,50 \\
\hline
\end{tabular}

Dari tabel di atas dapat dijelaskan bahwa dengan menerapkan metode pembelajaran Demonstrasi diperoleh nilai rata-rata hasil belajar peserta didik adalah 72,19 dan ketuntasan belajar mencapai 62,50\% atau ada 20 peserta didik dari 32 peserta didik sudah tuntas belajar. Hasil tersebut menunjukkan bahwa pada siklus pertama secara klasikal peserta didik belum tuntas belajar, karena peserta didik yang memperoleh nilai $\geq 75$ hanya sebesar $62,50 \%$ lebih kecil dari persentase ketuntasan yang dikehendaki yaitu sebesar $85 \%$. Hal ini disebabkan karena peserta didik masih merasa baru dan belum mengerti apa yang dimaksudkan dan digunakan guru dengan menerapkan metode pembelajaran Demonstrasi. 
Wahana Didaktika Vol. 18 No.1 Januari 2020 : 30-38

Tabel 3. Rekapitulasi Hasil Tes Formatif Pada Siklus II

\begin{tabular}{|c|l|c|}
\hline No. & \multicolumn{1}{|c|}{ Uraian } & Hasil Siklus II \\
\hline \hline 1. & Nilai rata-rata tes formatif & 76,56 \\
\hline 2. & Jumlah siswa yang tuntas belajar & 28,00 \\
\hline 3. & Persentase ketuntasan belajar & 87,50 \\
\hline
\end{tabular}

Dari tabel di atas diperoleh nilai rata-rata hasil belajar peserta didik adalah 76,56 dan ketuntasan belajar mencapai $87,50 \%$ atau ada 28 peserta didik dari 32 peserta didik sudah tuntas belajar. Hasil ini menunjukkan bahwa pada siklus II ini ketuntasan belajar secara klasikal telah mengalami peningkatan sedikit lebih baik dari siklus I. Adanya peningkatan hasil belajar peserta didik ini karena setelah guru menginformasikan bahwa setiap akhir pelajaran akan selalu diadakan tes sehingga pada pertemuan berikutnya peserta didik lebih termotivasi untuk belajar. Selain itu peserta didik juga sudah mulai mengerti apa yang dimaksudkan dan dinginkan guru dengan menerapkan metode pembelajaran Demonstrasi.

\section{PEMBAHASAN}

Melalui hasil peneilitian ini menunjukkan bahwa metode pembelajaran Demonstrasi dapat meningkatkan hasil belajar peserta didik. Hal ini dapat dilihat dari semakin mantapnya pemahaman peserta didik terhadap materi yang disampaikan guru (ketuntasan belajar meningkat dari pra Siklus, siklus I, dan II yaitu masing-masing 43,75\% , 62,50\%, dan 87,50\%. Pada siklus II ketuntasan belajar peserta didik secara klasikal telah tercapai. 


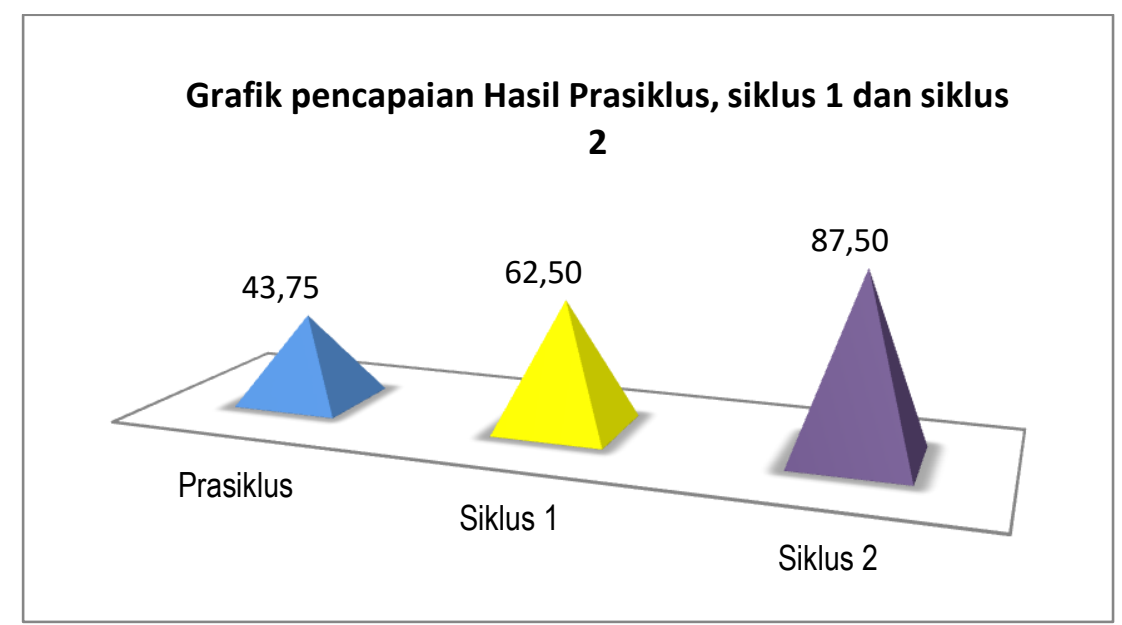

Grafik 1 Pencapaian Hasil Prasiklus, siklus 1 dan siklus 2

\section{SIMPULAN}

Dari hasil kegiatan pembelajaran yang telah dilakukan selama dua siklus, dan berdasarkan seluruh pembahasan serta analisis yang telah dilakukan dapat disimpulkan bahwa metode pembelajaran Demonstrasi dapat meningkatkan hasil belajar peserta didik yang ditandai dengan peningkatan ketuntasan belajar peserta didik dalam setiap siklus, yaitu pra siklus $(43,75 \%)$, Siklus $1(62,50 \%)$, dan siklus $2(87,50 \%)$.

Untuk melaksanakan metode pembelajaran Demonstrasi memerlukan persiapan yang cukup lama, sehingga guru harus mempu menentukan atau memilih topik yang benar-benar bisa diterapkan dengan metode pembelajaran Demonstrasi dalam proses belajar mengajar sehingga diperoleh hasil yang optimal. Dalam rangka meningkatkan prestasi belajar peserta didik, guru hendaknya lebih sering melatih peserta didik dengan berbagai metode pengajaran, walau dalam taraf yang sederhana, dimana peserta didik nantinya dapat menemukan pengetahuan baru, memperoleh konsep dan keterampilan, sehingga peserta didik berhasil atau mampu memecahkan masalah-masalah yang dihadapinya. 


\section{DAFTAR PUSTAKA}

Depdiknas. (2006). Permendinas Nomor 22 Tahun 2006 tentang Standar Isi untuk Satuan Pendidikan Dasar dan Menengah. Jakarta: BSNP.

Djamarah, Syaiful Bahri. (2000). Strategi Belajar Mengajar. Jakarta: Rineksa Cipta.

Djamarah, Syaiful Bahri. (2008). Psikologi Belajar. Jakarta: Rineka Cipta.

Slameto. (2010). Belajar dan Faktor-faktor yang Mempengaruhinya. Jakarta: Rineka Cipta.

Syah, Muhibbin. (2000). Pengertian Metode Demonstrasi. [online]. Tersedia: http://www.kajianpustaka.com/2012/10/metode-demonstrasi-dalam-bel ajar.html.

Syah, Muhibbin. (2005). Psikologi Belajar. Jakarta: PT Grafindo Persada.

Sanjaya, W. (2006). Strategi Pembelajaran. Jakarta: Kencana Prenada Media Group. 